\title{
The Library of Jacob de Wilde
}

\author{
Frans A. Janssen \\ Professor Emeritus, University of Amsterdam, Amsterdam, The Netherlands \\ f.a.janssen@uva.nl
}

\begin{abstract}
Like many wealthy citizens in the Dutch Golden Age, the Amsterdam civil servant Jacob de Wilde collected coins, gems, and small sculptures from Antiquity. Much has already been written about these collections, but De Wilde's book collection has been largely neglected. This article focuses on his library.
\end{abstract}

\section{Keywords}

Jacob de Wilde - book collecting - book auction catalogue - numismatics

\section{Introduction}

One of the collectors of antiquities in the Dutch Republic was Jacob de Wilde (1645-1721) from Amsterdam. As a Remonstrant he was a 'liberal' in religious matters, as Receiver General of the Admiralty in Amsterdam he enjoyed an income that enabled him to build a few important collections, which he proudly displayed in a 'gazophylacium' (treasury) in his house on Keizersgracht. As a collector, he focused on coins and medals, small sculptures and gems, both from Antiquity and later times. He also acquired prints and paintings, geometric instruments, as well as books. The secondary literature is expansive on the collector and his art collections, ${ }^{1}$ but his book collection has hardly received

1 The basis for all subsequent secondary literature is I. H. van Eeghen, 'De verzameling van Jacob de Wilde of het Museum Wildeanum op Keizersgracht 333', Jaarboek Amstelodamum, $5^{1}$ (1959), pp. 72-92. A clear overview is provided by L. J. Wagenaar, 'Jacob de Wilde (16451721) - an Amsterdam Collector', in: Numismatische Literatur 1500-1864, ed. Peter Bergaus (Wiesbaden 1995), pp. 99-116. See also various contributions in De wereld binnen handbereik. Nederlandse kunst- en rariteitenverzamelingen, 1585-1735, 2 vols., ed. Ellinoor Bergvelt \& Renée 


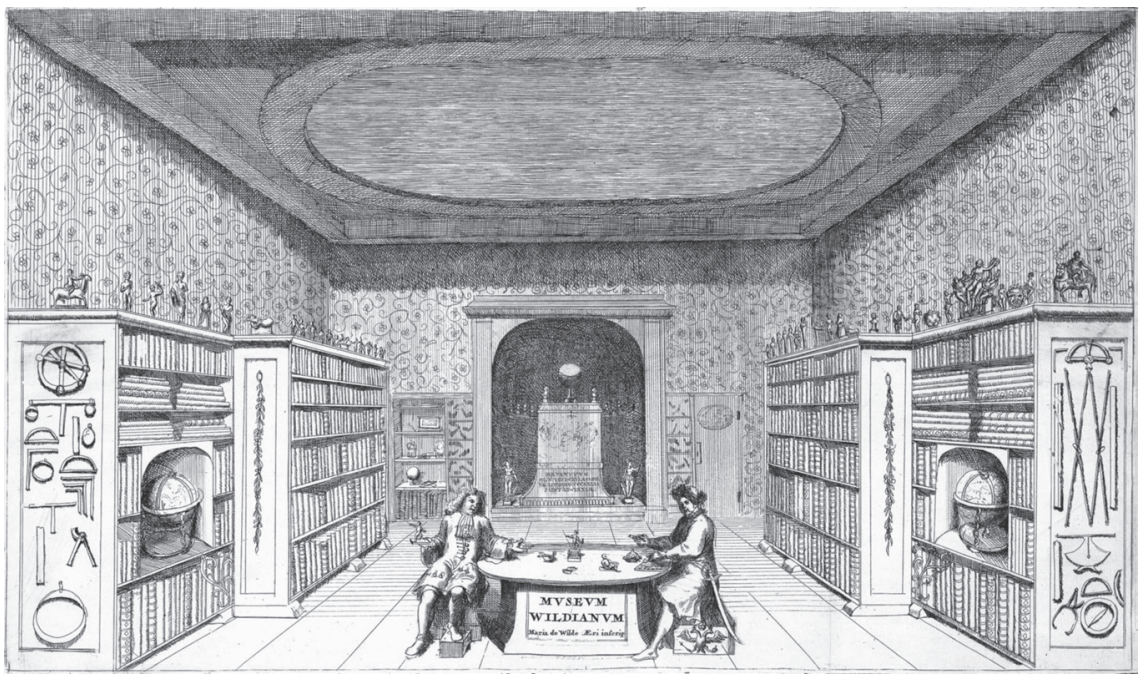

FIGURE 1 The library of Jacob de Wilde, etching by Maria de Wilde, in: Jacob de Wilde, Signa antiqua (1700)

AUTHOR'S COLLECTION

any attention, even though his library occupied a prominent place in his treasure chamber. This is obvious from the etching made by his daughter Maria in 1697 (fig. 1), while there is also a portrait etching made in 1701 (fig. 2) that shows a part of his library. Both are 'drawn from life'. In this article I will first briefly discuss De Wilde's art collections, chiefly basing myself on the literature mentioned in note 1, without specifying these sources in separate footnotes. Next I will turn to the main topic of this contribution, the library that has received such scant attention in the secondary literature. The interest was primarily in the objects; the book collection was neglected by the art historians.

Kistemaker (Zwolle-Amsterdam 1992); various contributions in Peter de Grote en Holland, ed. Renée Kistemaker et al. (Bussum-Amsterdam 1996); Carolien M. P. Voigtmann, De verzameling Jacob de Wilde. Onderzoeksverslag (n.p. 20o1); olim in Het Koninklijk Penningkabinet (The Royal Numismatic Cabinet), now in De Nederlandsche Bank, Amsterdam; offers numerous details); Alice Souguir, De bezoekers van het Museum Wildianum, 1689-1720 (Amsterdam 2013, MA Thesis); Marianne Maaskant-Kleibrink, Catalogue of the Engraved Gems in the Royal Coin Cabinet The Hague (The Hague-Wiesbaden 1978); Bert van den Bercken \& Selkit Verberk, Pracht en precisie. Kleine meesterwerken in steen (Leiden 2015); 'Jacob de Wilde', in: Wikipedia (English version; gives useful references: https://en.wikipedia.org/wiki/Jacob_de_Wilde, last accessed 26 May 2020). My thanks to Frank Mertens, who compiled a genealogy of the De Wilde family on my behalf (e-mail 20.02.2020). 


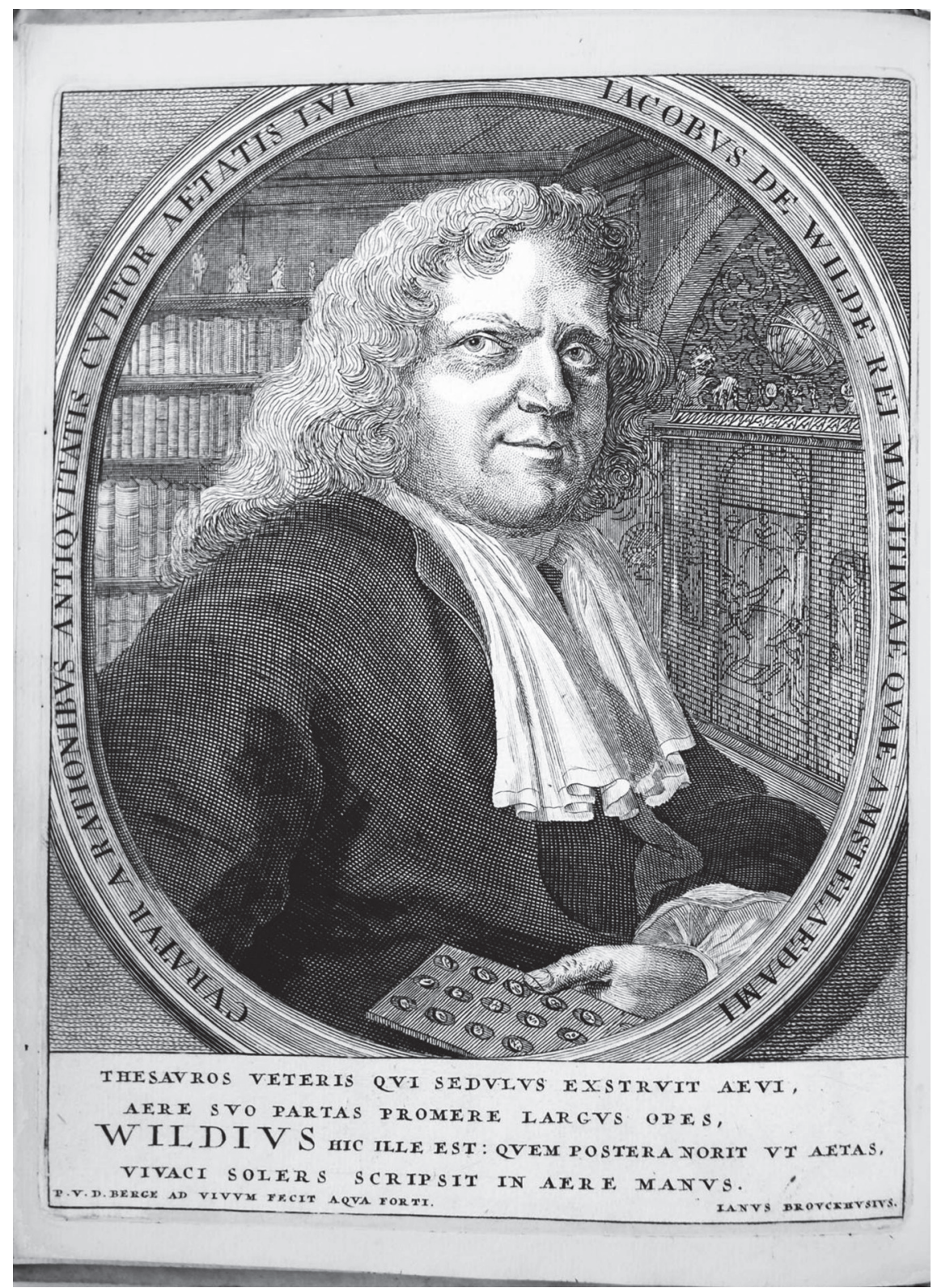

FIGURE 2 Portrait of Jacob de Wilde, etching by Pieter van den Berge, in: Jacob de Wilde, Gemmae selectae (1703).

AUTHOR'S COLLECTION 


\section{The Museum Wildianum}

De Wilde compiled separate anthologies of his collections of coins, sculptures and gems, for which he wrote the texts himself (mainly quotations from classical authors, occasionally from secondary sources), and had them published in a large quarto format at his own expense. The first of these was devoted to the richest part of the collection, the (chiefly Greek) coins and (usually contemporary) medals cast in bronze, silver or gold: Selecta numismata antiqua ex musaeo Jacobi de Wilde of 1692 (fig. 3). The 'wild man' in the publisher's device is a playful allusion to De Wilde's name, but also refers to Hercules, whose image is to be found in the collection in the form of coins, gems and sculptures (fig. 4). The device on the title page of Selecta numismata was etched by Adriaan Schoonebeek, a student of Romeyn de Hooghe and the mentor of De Wilde's daughter Maria; the images of the coins are also by his hand.

Since the Renaissance, coins from Antiquity had been a favourite subject to collect and study among the cultured classes. They were not regarded as aesthetic objects, but as sources for the knowledge of Antiquity. As with the study of the other objects, the investigation of coins involved a new approach to the history and culture of the ancient Greeks and Romans: not only texts but also small objects from Antiquity were collected and studied. From the sixteenth century on, numerous numismatic works were published as a result. In the affluent seventeenth century there were in Amsterdam alone dozens of collectors who sought to acquire ancient and modern coins and commemorative medals. De Wilde's collection was the largest one, although to date none of his coins and medals have been identified in existing collections. It is possible that a number of the coins were replicas or forgeries. Like the gems, the coins were also valued for their iconographic value. ${ }^{2}$

Eight years after this first anthology, a second one saw the light of day. It was devoted to the 'signa', small sculptures from Antiquity, mainly of Greek and Roman origin but also a few Egyptian ones: Signa antiqua e museo Jacobi de Wilde [...] et per Mariam filiam aeri inscripta of 1700. The engraved title page shows Apollo in the company of Mercury and Maria de Wilde (fig. 5). The sculptures in copper, bronze and occasionally in marble, were etched by De Wilde's daughter Maria, together with the quotations from classical authors (fig. 6). It is now assumed that many of them were replicas or imitations made

2 See for instance André Alciat, Emblemata. Les emblèmes, ed. Pierre Laurens \& Florence Vuilleumier Laurens (Paris 2016), pp. xx-xxi, 45, 76, 130, 156; cf. Van den Bercken \& Verberk, op. cit. (n. 1), pp. 43-5. 


\section{S E L E C T A NUMISMATA A N T I Q U A; EX MUSAO} JACOBI DE WILDE.

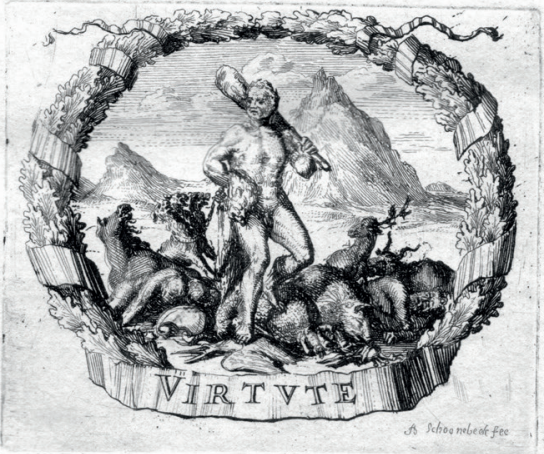

A M S T E L O D A M I,

Sumptibus Authoris. C1 $010 \mathrm{C} \mathrm{XXXX1 \text {. }}$

FIGURE 3 Jacob de Wilde, Selecta numismata (1692), title page. AUTHOR'S COLLECTION 


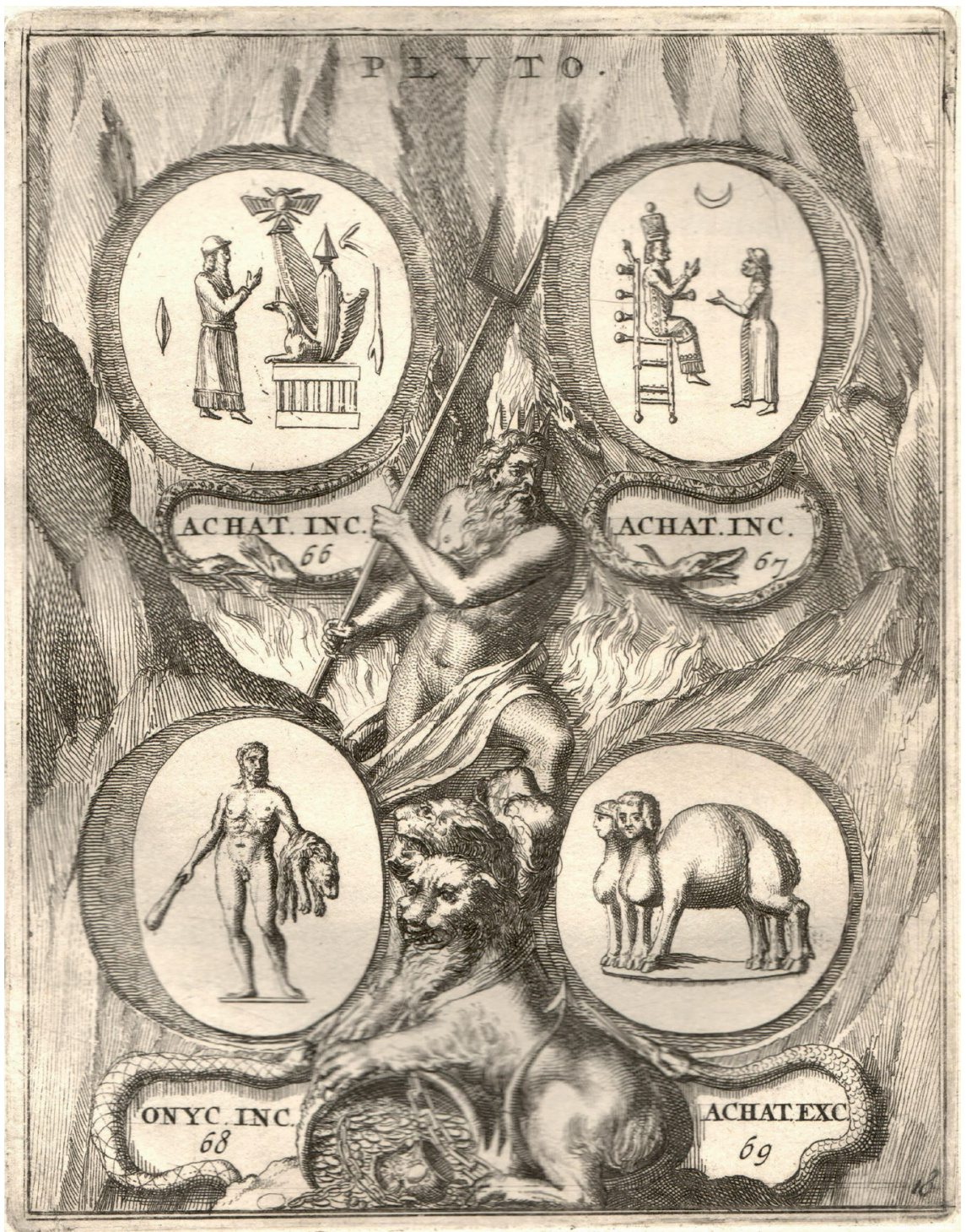

FIGURE 4 Hercules, etching by Adriaan Schoonebeek, in: Jacob de Wilde, Gemmae selectae (1703), tab. 18 , no. 68.

AUTHOR'S COLLECTION 


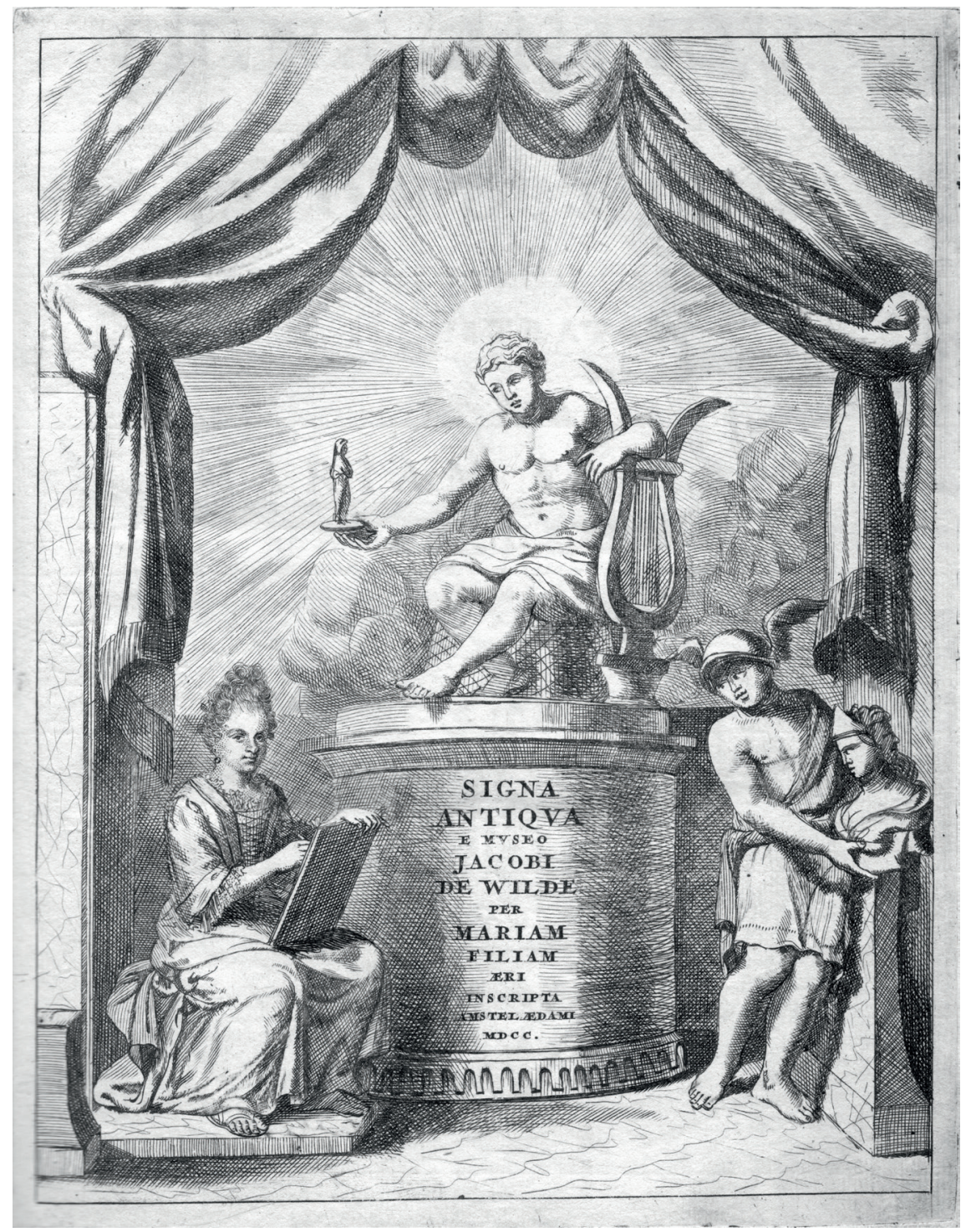

FIGURE 5 Title print, etching by Maria de Wilde, in: Jacob de Wilde, Signa antiqua (1700).

AUTHOR'S COLLECTION 


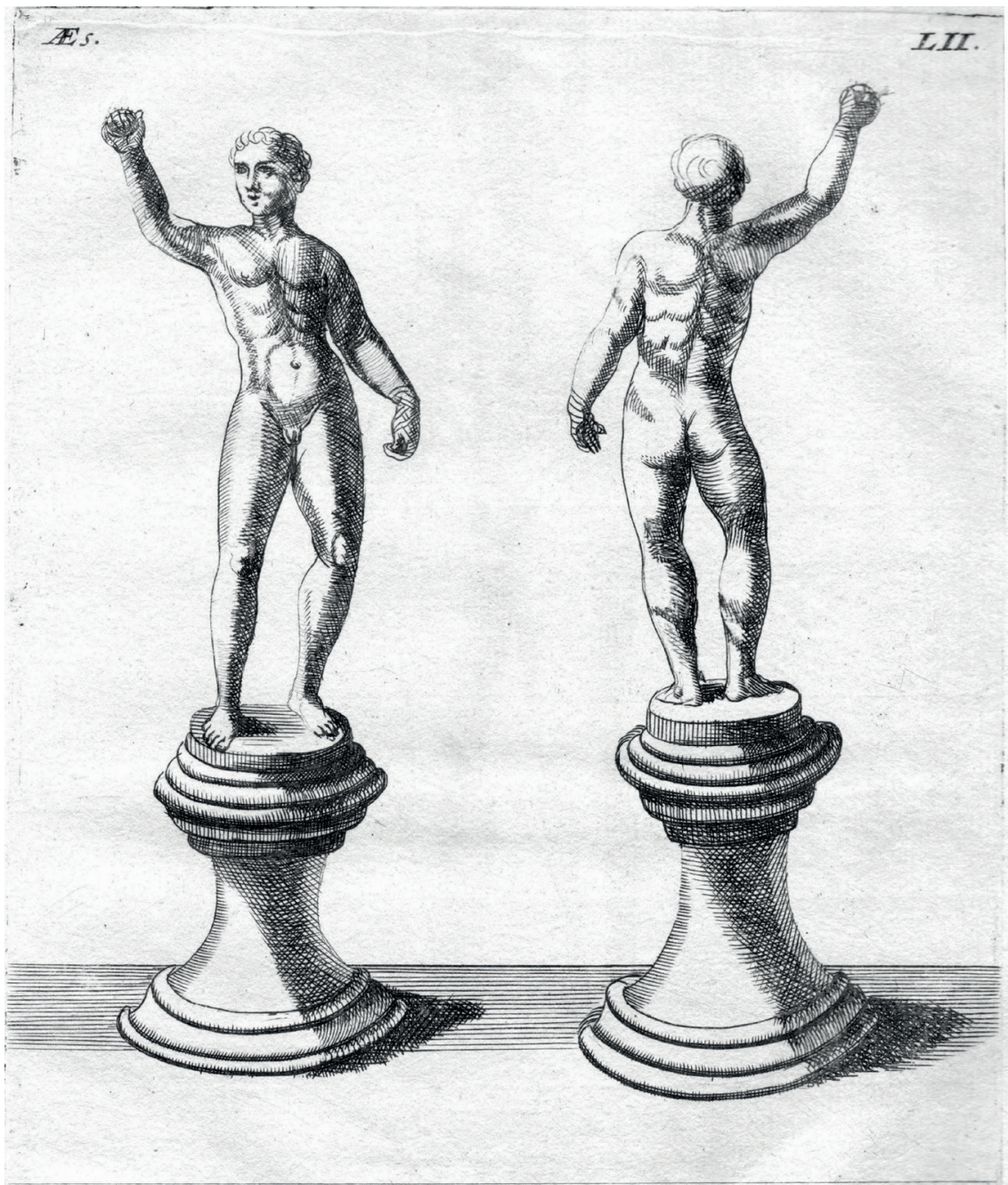

Queritur huic alius; nec quis quam ex agmine tanto Audet adire virum, manibusque inducere caftus. Maria de Witde Eri injerip.

Virg. I In. I. $\cdot 7 \cdot 37^{8}$.

FIgURE 6 Dares (from Virgil, Aeneid), etching by Maria de Wilde, in: Jacob de Wilde, Signa antiqua (1700), no. 52.

AUTHOR'S COLLECTION 
in the Renaissance. Only one of these objects has so far been identified: an authentic marble urn (Rome, $c .100 \mathrm{AD}$ ), which is now kept in the Rijksmuseum van Oudheden (National Museum of Antiquities) in Leiden (no. 56 in Signa antiqua).

Anyone collecting coins in the Renaissance also focused on gems, usually precious stones with carved images. They are known as cameos when the image is cut in relief and intaglios when engraved. The latter, which could be used as seals, were also mounted in rings. The anthology from this glyptic collection appeared in 1703: Gemmae selectae antiquae e museo Jacobi de Wilde. The etchings were by Adriaan Schoonebeek, who had left for Moscow in the middle of 1698 to enter the service of Tsar Peter the Great but who occasionally sent copperplates to Amsterdam from his new domicile. ${ }^{3}$ The type of stone is noted on the images of the carved stones. Part of De Wilde's glyptic collection has been traced: the gems that were originally held in the Koninklijk Penningkabinet (the Royal Numismatic Cabinet), were transferred to the Rijksmuseum van Oudheden (National Museum of Antiquities) in Leiden in 2013. Among them is an intaglio gem with an image of Hercules (1st century CE), for De Wilde an allusion to his device of the wild man. ${ }^{4}$ It has also been established with respect to the age of the gems that many date from the fifteenth, sixteenth or seventeenth centuries; some are downright forgeries.

Apart from these three anthologies, incorrectly referred to as catalogues in the secondary literature, there are a few other sources available to explore De Wilde's art collections. An important source which has not yet been studied are a number of manuscript lists of coins of De Wilde's collection, which were compiled between c. 1685 and c. 1700 (now in the Koninklijke Bibliotheek/ National Library of the Netherlands, The Hague, 74 D15). In 1722, shortly after De Wilde's death, a list of coins and medals was produced with an eye to a possible purchase by Tsar Peter the Great; though the sale never happened. ${ }^{5}$ What has been the subject of previous study is the Museum Wildianum (1740/1741), the auction catalogue of the three sub-collections together amounting to more than 3,60o objects, which was auctioned some twenty years after his death. ${ }^{6}$

3 See Frans A.Janssen et al., 'Adriaan Schoonebeek's Etching Manual (1698):Edition, Translation, Comment', Quaerendo 40 (2010), p. 114; a preliminary sketch of one of Schoonebeek's etchings in Gemmae selectae is kept in the Hermitage, Saint Petersburg, Russia.

4 Van den Bercken \& Verberk, op. cit. (n. 1), p. 55 (with ill.) = Gemmeae selectae (1703), tab. 18, no. 68 (see fig. 4 above), cf. tab. 40, no. $15^{\circ}$.

5 The list is reproduced in Jozien J. Driessen-van het Reve, De Kunstkamera van Peter de Grote (Hilversum 2006), pp. 308-9.

6 A summary is in Voigtmann, op. cit. (n. 1), appendix ii. There are two issues of this catalogue, one dated 1740 on the title page, one dated 1741 . 
In 1768 there was still another auction which included De Wilde's paintings, furniture and mathematical instruments (an auction catalogue is not known).

Not only the three anthologies but also other publications feature panegyrics on the great collector. Such accolades are also to be found in his guest book, which has largely been preserved: the greater part is kept in the Stadsarchief Amsterdam. Princes (including Tsar Peter, who visited the 'museum' on more than one occasion), scholars, numismatists, writers, artists and fellow collectors (in all more than 700 names, mainly of foreigners) expressed their admiration in their inscriptions. In addition, there are the almost ten pages devoted to the visit which Zacharias Conrad von Uffenbach (himself a collector of coins) paid De Wilde in 1711, in his Merkwürdige Reisen durch Niedersachsen, Holland und Engelland (1753-4). The library hardly ever gets a mention in any of these tributes.

The Museum Wildianum was primarily a collection of art ('art' in the modern sense of the word), which mainly consisted of artefacts from Antiquity or objects that passed as such. As has been mentioned, the interest did not so much lie in the aesthetic enjoyment of the objects as in the contribution they might have to offer to the knowledge of Antiquity. There were many such collections of coins, gems and sculptures from Antiquity in the prosperous Golden Age. They served to enhance the cultural status of the collector. The collection built by De Wilde differs from the collection profile of several other Dutch collectors around 1700. Here I shall only mention the collections of Nicolaas Witsen and of Simon Schijnvoet, which did not only feature coins and medals, sculptures and gems, but also natural objects like shells, animal preparations and manmade objects such as ethnographic items. Such collections were more comprehensive than a collection of antiquities, they were real cabinets of curiosities, Wunderkammern, which is why they were visited by Tsar Peter (it was undoubtedly Witsen who had introduced De Wilde to the Tsar). ${ }^{7}$ Schijnvoet's numismatic collection was described in S. Schynvoets muntkabinet der Roomsche [= Roman] keizers en keizerinnen, which was published in 1795 and featured images of Roman coins accompanied by historical comments provided by the poet Abraham Bogaert.

7 Resp. Marion Peters, De wijze koopman. Het wereldwijde onderzoek van Nicolaes Witsen (16411717) (Amsterdam 2010), esp. chapter 10 and appendix ix; G. M. van de Roemer, De geschikte natuur: theorieën over natuur en kunst in de verzameling van zeldzaamheden van Simon Schijnvoet (1652-1727) (Amsterdam 2005, MA Thesis) available online at http://dare.uva.nl/ document/139406), esp. chapter 2. De Wilde's art collection is sometimes incorrectly considered as one of the Wunderkammern or cabinets of curiosities, e.g. in Florence Fearrington, Rooms of wonder (New York 2012), pp. 53-4; Paul Grinke, From Wunderkammer to Museum (London 2006), pp. 78-9. 


\section{The Library}

There are three sources for the library of Jacob de Wilde. First of all there is the previously mentioned etching of the library's interior in his house on Keizersgracht 333, made by his daughter Maria late in 1697 or not long afterwards; it is included in Signa antiqua (1700) and has often been reproduced (see fig. 1). The etching was made when Tsar Peter the Great visited De Wilde's house on 13 December 1697. The Tsar can be identified by the coat of arms perched against the foot stool and the fur hat. In his right hand he holds a gem, taken from the drawer placed before him on the table. There are two more gems on this table, along with four sculptures. Jacob de Wilde holds a sculpture in his right hand (no. $5^{2}$ from Signa antiqua, see fig. 6), and a coin in his left hand. The antique sculptures are on top of the bookcases. Some can be identified as they were reproduced in Signa antiqua, for instance the equestrian statuettes on the left and right at the front of the bookcases (respectively nos. 44-5 and $5^{\circ}$ ), the stork on the right at the back (no. 13). The numismatic cabinet, designed in a more classicist style and called 'nummophylacium', is in a niche in the back (fig. 7). The cabinet also contained medals and gems. The door has been decorated with a group of mythological figures, with Hercules on the right. Cabinets containing gems or casts of gems in the drawers were also known as 'dactyliothecae'. Selecta numismata antiqua includes four etchings of the numismatic cabinet by Adriaan Schoonebeek, with closed (see fig. 7) and opened doors, which were painted with allegorical scenes devised by the owner. These etchings were also reproduced in Afbeeldinge van het medaliekabinet van Jacob de Wilde (1691). Placed on top of the cabinet we find a globe and a number of busts of Roman emperors (for the illustrations see nos. 57-6o in Signa antiqua); the cabinet is flanked by metal statues of Minerva on the left and Apollo on the right (see fig. 1). This numismatic cabinet is featured in the previously mentioned auction catalogue Museum Wildianum of 1740/1741 (p. 155), but it has not survived, which is also the case for the numismatic cabinet of the collector and merchant Nicolas Chevalier, which strongly resembled that of De Wilde. ${ }^{8}$ The bookcase on the left in the etching of De Wilde's library features a globe, a few sculptures, a clock and the previously mentioned urn.

8 Illustrations in De wereld binnen handbereik, op. cit. (n. 1), vol. 1, pp. 87, 280; vol. 2, 92; cf. the prints in Nicolas Chevalier, Remarques sur la pièce antique de bronze [...] (3rd ed. Amsterdam 1694; Utrecht 1704); see also the description and some of the illustrations in Description de la chambre des raretez de Nicolas Chevalier (Koninklijke Bibliotheek (National Library of the Netherlands), The Hague MS 1694), pp. 1-58. See also Schijnvoet's cabinet in Abraham Bógaert, S. Schynvoets muntkabinet (Amsterdam 1695), in the prelims, and see Fearrington, op. $\operatorname{cit}($ n. 7$)$, p. 46. 


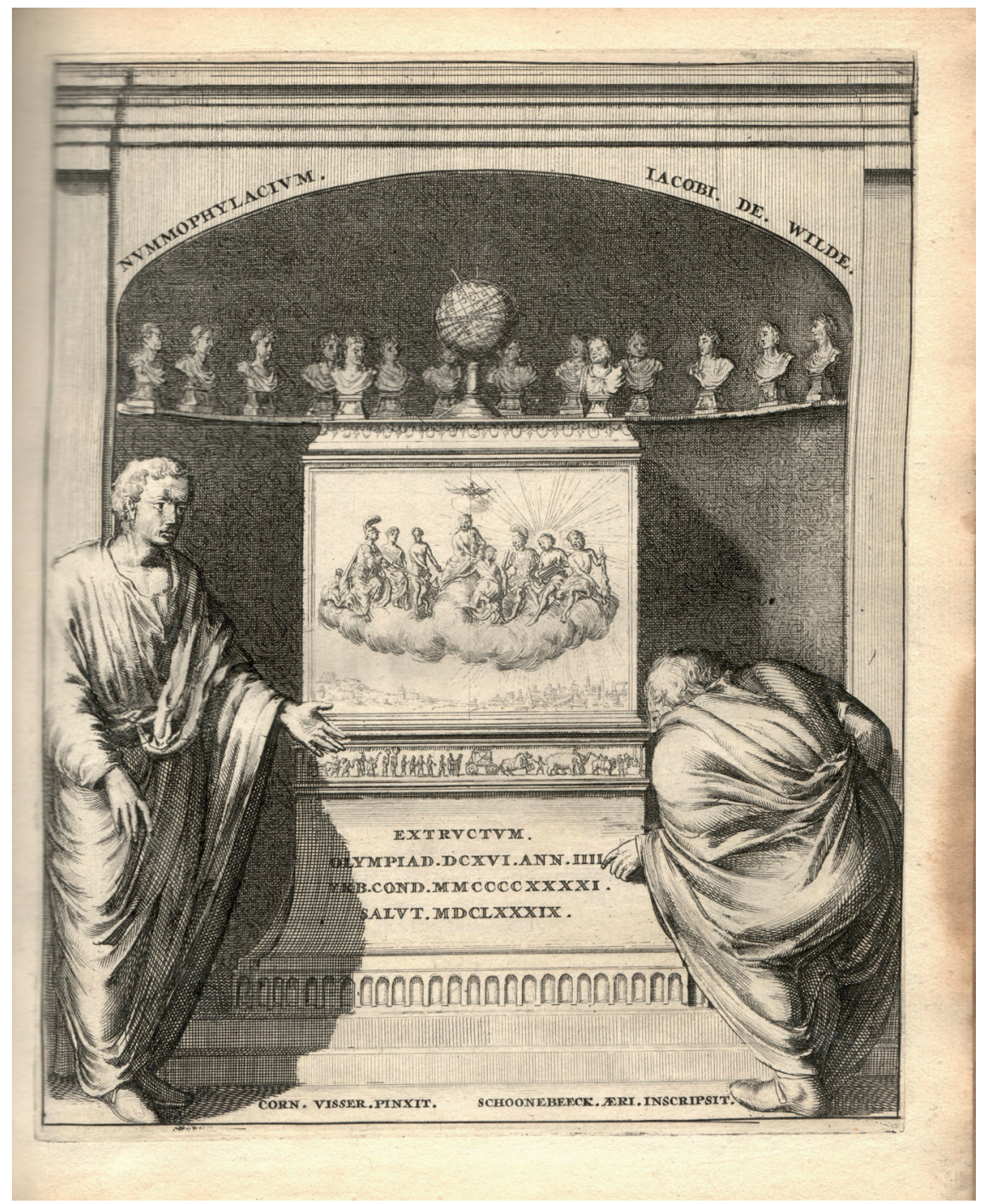

FIGURE 7 'Nummophylacium', etching by Adriaan Schoonebeek, in: Jacob de Wilde, Selecta numismata (1692), prelims.

AUTHOR'S COLLECTION 
On the sides of the front bookcases left and right are mathematical instruments, standard items of any Wunderkammer. They were included in the 1722 auction catalogue of the books which will be discussed later (pp. 73-4, some of them were also featured in the auction of 1768). Among the objects on the left are a circle, a T-square, a protractor, a sector; on the right a graphometer, a parallel ruler, a pantograph, a goniometer and an angle gauge. ${ }^{9}$

Most of the space in the room is occupied by the books, which are symmetrically arranged according to format in four bookcases. The front cases contain the books in folio and, lying on their backs, those in large folio. A niche in the middle of each bookcase holds a terrestrial and a celestial globe, which according to the book auction catalogue (p. 73) were made by the firm of Blaeu; a mechanism made it possible to swivel them out, as is illustrated in Uffenbach's account. The two bookcases in the rear contained the books in quarto, octavo and duodecimo (from the bottom shelves to the top). The depth of these book cases is approximately half of that of the folio-format book cases, and they jut out. The spaces between these cases and the walls possibly served as storage space. The lines on the floor suggest that the floor consists of wooden boards.

Maria de Wilde's etching conveys the image of a library rather than an art cabinet or Wunderkammer; what we see is a book collection adorned with antiquarian objects. The print seems true to life, which is otherwise rarely the case with interiors of book and art collections and Wunderkammern. The image of the library in this etching resembles that of the library and the numismatic cabinet as depicted in the etched portrait of De Wilde (see fig. 2). A visit to De Wilde's still existing house on Keizersgracht 333 in Amsterdam showed that the width of the layout in Maria's print was not exaggerated: the first floor, where the library and art collection were situated according to Uffenbach, stretches across three large windows..$^{10}$ Only very rarely do we find an image of a private library that can more or less compare to this one, with or without a collection of art or curiosities. ${ }^{11}$

9 I owe the identification of these objects to Jan De Graeve, land surveyor in Brussels.

10 My thanks to the present owners who welcomed me to their home in 2014.

11 A print from 1723, probably the library of the geographer Nicolas De Fer (1723; see Histoire des bibliothèques françaises, vol. 2. Les bibliothèques sous l'Ancien Régime 15301789, ed. Claude Jolly (Paris 1988), p. 334); the library of the merchant Caspar Friedrich Neickel (1727; see Fearrington, op. cit. (n. 7), pp. 48-9); the bookplate of Zacharias von Uffenbach — designed in 1704-is clearly inspired by Maria's etching: reproduced in e.g. G. A. E. Bogeng, Die grossen Bibliophilen, vol. 2 (Leipzig 1922), illus. 173 (there is also an illustration of his library dating to 1729). See also the bookcases in a number of prints of Nicolas Chevalier's 'chambre des raretez', op. cit (n. 8). Maria de Wilde's etching is possibly the oldest illustration of a private library. 


\section{The Auction Catalogue}

The main source for De Wilde's library is of course the auction catalogue of his book collection (fig. 8 and fig. 9): Catalogus [...] librorum [...] Jacobi de Wilde, which was compiled shortly after his death (Amsterdam 1722). ${ }^{12}$ The title page also mentions that the collection mainly features books on classical studies and numismatics and that the auction will take place in the house of the deceased, on Keizersgracht [no. 333], directly opposite the city theatre. It is well known that auction catalogues of private libraries do not always reflect their actual contents: not only could heirs have selected books for themselves, but auctioneers were also in the habit of adding books, especially from their own stock (the practice is called 'salting'; Dutch: 'insteken'). ${ }^{13}$ It is also necessary to realise that no distinction was made between recent and older books: the qualifications 'antiquarian' and 'bibliophile' books rarely apply before the first half of the eighteenth century. As a rule, sixteenth-century books, which in this catalogue are rare for that matter, must be regarded as ordinary books, such as Hadrianus Junius, Batavia (Antwerp 1568; quarto no. 192); this is even the case for a work like the so-called 'Deux-aes Bible': De Wilde owned a copy of one of its many editions, namely a copy of one of the two Delft editions of 1582 (folio no. 288). An exception must be made for works that were already considered remarkable in his own time, such as a manuscript book of hours (octavo no. 139).

De Wilde's collection numbered c. 1,36o works, slightly fewer than the libraries of the previously mentioned contemporary collectors Schijnvoet and Witsen, which contained respectively c. 1,90o and c. 2,00o books. ${ }^{14}$ Schijnvoet, who did not read Latin, mainly owned books in Dutch. Scholarly libraries were much larger; the auction catalogue of that of Nicolaas Heinsius (1682)

12 Microfiche in Book Sales Catalogues, CAT 1948, MF 3227 , also available in Book Sales Catalogues Online. Two copies are known to have been preserved: British Library London, S.C. 104: 2; Herzog August Bibliothek, Wolfenbüttel, Bc Kapsel 10: 23.

13 On the research of book catalogues see e.g. Malcolm Walsby, 'Book Lists and their Meaning', in: Documenting the Early Modern Book World. Inventories and Catalogues in Manuscript and Print, eds. Malcolm Walsby \& Natasha Constantinidou (Leiden-Boston 2013), pp. 1-24; Hannie van Goinga, Alom te bekomen. Veranderingen in de boekdistributie in de Republiek 1720-180o (Amsterdam 1999), esp. pp. 26, 186.

14 See resp. Van de Roemer, op. cit. (n. 7), pp. 62-4, 198, 201-4 (auction of his books: Een versameling van veele kleurlyke boeken [...] (Amsterdam 1728)) and Peters, op. cit (n. 7), chapter 9 and appendix 2 (auction of his books: Bibliotheca nitidissima [...] (Amsterdam 1747)). The poet and numismatist Joachim Oudaan owned c. 1,050 books (auction of his books: Catalogus van boeken [...] (Rotterdam 169o)). A detailed comparison between De Willde's auction catalogue and that of other collectors would require a separate study. 


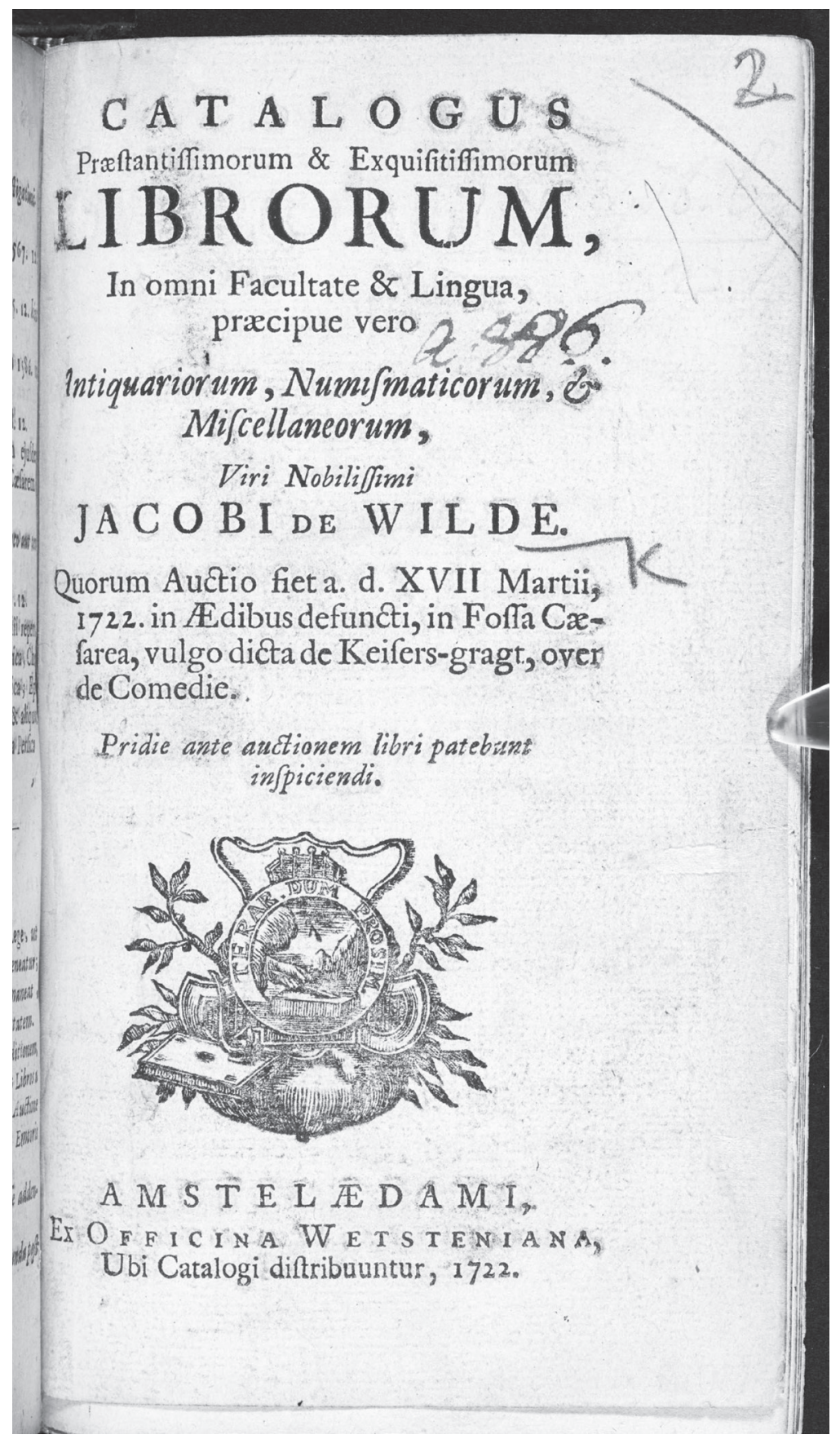

FIGURE 8 Catalogus [...] librorum [...] Jacobi de Wilde (1722), title page. BRITISH LIBRARY, LONDON, S.C. 104:2 


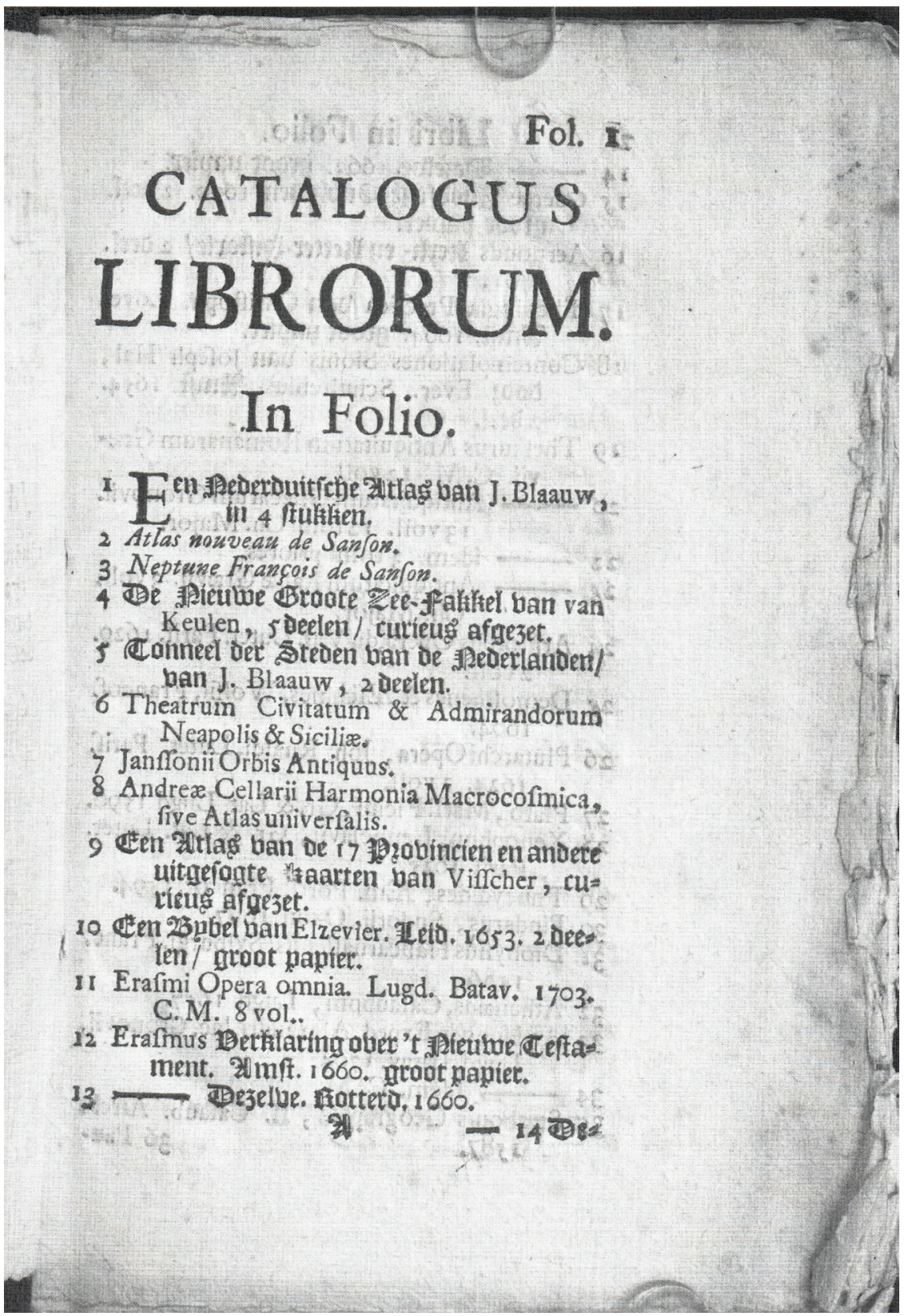

FIgURE 9 Catalogus [...] librorum [...] Jacobi de Wilde (1722), p. 1. BRITISH LIBRARY, LONDON, SC 104:2 
included c. 13,00o books. The auction catalogue of De Wilde's library does not arrange the books according to separate disciplines (theology, law, medicine, history, etc.) but according to format (folio, quarto, octavo, duodecimo), as in Schijnvoet's catalogue. It was common practice to arrange the books according to disciplines and, within these, according to format, as in Witsen's catalogue. De Wilde's 1722 catalogue has no thematic arrangement. There are nevertheless some clusters of books to be found within the several formats occasionally that clearly belong to the same category, such as numismatic literature (folio nos. 55-82, quarto, nos. 12-65, octavo, nos. 6o-67), Latin editions of the classics (folio nos. 24-47, octavo, nos. 1-47), French translations of the classics (quarto, nos. 216-26; octavo, nos. 272-318), Dutch literature (quarto, nos. 346-364); works in French and in Dutch are listed after the Latin titles. The catalogue undoubtedly reflects the original arrangement of the books in the bookcases; when the catalogue was compiled, the books were taken from the shelves one by one or in small bunches, a not uncommon practice. ${ }^{15}$ Although we occasionally encounter Sammelbände, the compiler of the catalogue will probably have overlooked them here and there. Latin titles were traditionally set in Roman type in catalogues, French and Italian ones in italics and Dutch and German in black letter (see fig. 9). (De Wilde did not own any books in English). Almost invariably, place and year of edition are listed for the larger formats, but hardly ever for the smaller ones. The title description usually (more or less) follows the wording on the title page, although errors and sloppy transcriptions are not rare.

Works dealing with De Wilde's three collecting areas-coins, gems, and sculptures-are amply represented in the catalogue. ${ }^{16}$ A number of numismatic titles already date from the sixteenth century. He owned several publications (folio nos. 58-61, quarto nos. 19-22) by the French numismatist Jean Foy-Vaillant, to whom he sent a dedication copy of Signa in 1700 (now in the Fondation Custodia, Paris); he also had several editions of Foy-Vaillant's Numismata Imperatorum Romanum. The library furthermore contained a number of works by that other French numismatist and contemporary of FoyVaillant, Charles Patin, including one of the editions of his Histoire des médailles (octavo no. 388). The Amsterdam collector had praised the author in the

15 See B. van Selm, Een menighte treffelijcke boecken. Nederlandse boekhandelscatalogi in het begin van de zeventiende eeuw (Utrecht 1987), pp. 88-9.

16 On these sources in general see e.g. Numismatische Literatur, op. cit. (n. 1), passim; Margaret Daly Davis, Archäologie der Antike. Aus den Bestanden der Herzog August Bibliothek 1500-1700 (Wiesbaden 1994), pp. 97-125. A specialist in the literature of coins, gems and sculptures would be able to provide a more detailed account of the book collection than is here possible. 
preface of his Selecta numismata of 1692. The poet and coin collector Joachim Oudaan, a compatriot of De Wilde, belonged to a slightly older generation. De Wilde acquired from his estate a collection of medals, sketches of these medals and a medal cabinet. ${ }^{17}$ De Wilde owned both the first edition of 1664 of Oudaan's Roomsche mogentheid, which describes Roman history as illustrated by its coins, as well as the augmented fifth edition of 1706 (quarto no. 333 and 64). It goes without saying that he also possessed the previously mentioned catalogue of Schijnvoet's coin collection of 1695 (octavo no. 167), which like Oudaan's and De Wilde's works linked the coins from Antiquity to historical details.

De Wilde owned both the first edition of Abraham Gorlaeus' Dactyliotheca, a major work exclusively devoted to gems first published in 1609, as well as the revised and augmented edition provided by Jacobus Gronovius in 1695 (quarto nos. 69-70). The 1695 edition noted the material (in particular the type of stone used) of the object and added a commentary, just as De Wilde would do in his Gemmae of 1703 .

Collecting coins, gems and sculptures was regarded as a contribution to the knowledge of Antiquity, and so it is to be expected that the catalogue features many works on the Greek and Roman world. There are six works by the classical scholar Johannes Meursius dating from 1631-1687 (quarto nos. 160-165). A few works by the polymath Athanasius Kircher published between 1652-1678 (folio nos. 129-132) must also be mentioned in this connection. In connection with these books we must note the many text editions of classical authors, mainly in French or in Dutch translation, such as Joost van den Vondel's translation of Virgil, present in both a quarto edition (no. 349, 166o) and in a duodecimo edition (no. 210, one of the editions that appeared between 1646-1714).

De Wilde's library reveals his great interest in iconographic works, including emblem books. He owned a wide range of works which would only come to be thoroughly studied by art historians in the twentieth century. The discipline of iconography might be said to start with the frequently reprinted Hieroglyphica, the first edition of which appeared under the fictitious name Horapollo in 1505. This book, which offers a symbolical interpretation of the Egyptian hieroglyphs, is the foundational work of emblematic literature. De Wilde's library contained one of the French adaptations (octavo no. 402). Pierio Valeriano wrote a comprehensive reference work under the same title which was first

17 See Judith Tadema, 'Een ambachtsman met "beschaafde” hobby's: de dichter en verzamelaar Joachim Oudaan', De zeventiende eeuw 20 (2004), p. 213, n. 22. For the auction catalogue of Oudaan, see n. 14 above; the drawings were not included in De Wilde's auction catalogues. See also Voigtmann, op. cit. (n. 1), appendix iv. 
published in 1556 and was often reprinted; our Amsterdam collector owned a French translation of 1615 (folio no. 207). Cesare Ripa's seminal Iconologia was a book that was frequently consulted in the seventeenth century. The first edition of this work, which was often reprinted and adapted, appeared in 1593 . At the time this book was a practical manual for artists, today it is the bible of iconological studies. On the shelves of De Wilde's library stood a copy of the first edition of the Dutch translation of 1644: Iconologia, of uytbeeldingen des verstands (quarto no. 370). Potential buyers leafing through the auction catalogue were regaled with a batch of emblem books, starting with Emblemata by the initiator of the genre, Andrea Alciati; many reprints were to follow after the first edition, published in 1531. Of this work De Wilde owned an edition with a commentary by Claude Mignault, bound in one volume together with the emblem books by Hadrianus Junius and Johannes Sambucus (duodecimo no. 22). These may have been copies of editions by Christopher Plantin, who printed these volumes several times c. 1580. Of the contemporary volumes I would like to mention an author and illustrator from De Wilde's circle: Ludolf Smids's Pictura loquens of 1695, with etchings by Adriaan Schoonebeek (octavo no. 70). As in numerous other emblem books, the images are here accompanied by quotations from the classics, which is also to be found in De Wilde's three anthologies of his collections.

A highly noteworthy book owned by De Wilde is a copy of the nowadays so renowned Poliphilus, although interestingly it was not one of the large and sumptuously illustrated Italian editions (1499, 1545), or any of the French counterparts $(1546,1554,1561)$, but an adaptation of the French translation by the Mannerist Béroalde de Verville, published in a small format under the title Le tableau des riches inventions (quarto no. 128). The French adapter not only gave an alchemical twist to the novel, but clearly also regarded the work as an iconographic manual, as he added an index of symbols. We see that both signifier and signified are included as entries, as for example 'Victoire' and 'Palme'.18

De Wilde's interest in iconography has everything to do with the way he looked at his coins and gems. He also saw them as symbolic representations, as is clear from the indices in the two works he devoted to these collections. Among the entries in the index to Selecta numismata, for instance, are both the concept 'Victoria' and one of its symbols, 'Palma' (see also under 'Symbola'). Oudaan, too, included symbols in his index to his numismatic manual Roomsche mogentheid of 1706 . The symbolic programme of the painted decorations on De Wilde's numismatic cabinet (see fig. 7) had been devised by the author and collector himself: 'Die Sinnbilder, so darauf waren, sind schön, und

18 See Frans A. Janssen, 'Béroalde's Poliphilus', Quaerendo 39 (20o9), pp. 26-33. 
von guter Invention' (The symbols on them are beautiful and well invented), Uffenbach noted in his account of the visit he had paid De Wilde.

Theology is only modestly represented. Of course, De Wilde had a copy of the well-known historical work by Gerard Brandt, Historie der reformatie, in one of the editions of which the first part had appeared in 1677 (quarto no. 325). More striking, however, are a few esoteric titles. The medical handbook Basilica chymica by Oswald Croll is based on the hermetic and alchemical thought of the physician Paracelsus (first edition 1609, frequently reprinted, quarto no. 273). Giovanni Battista della Porta associated magic with natural philosophy in his La magie naturelle (first Latin edition 1658, first French translation 1565, duodecimo no. 147). As a collector of gems, De Wilde will have been interested in the magical powers attributed to precious stones as discussed in this work. Thoroughly magical is a work entitled Clavicules de Salomon (folio no. 226), the full title of which we know because Uffenbach quoted it in the account of his visit. ${ }^{19}$ The work contains invocations for summoning demons. A French adaptation based on a Latin original circulated in numerous manuscripts in the seventeenth but especially in the eighteenth century. That it was a curious book to have encountered in a Calvinist milieu in seventeenth-century Amsterdam, is clear from the attention Uffenbach lavished on the book.

De Wilde's stock of literary works was not really impressive: Dutch authors from the Golden Age (Vondel, Hooft, Huygens, Cats), a Dutch translation of Montaigne of 1692 (quarto no. 376) and Fénelon (De gevallen van Telemachus, a copy either of the 1700,1715 or 1720 edition, octavo no. 190), whose moralistic novel Télémaque caused a frisson of excitement because it had immediately been banned in France in 1699 when the first part of the first edition came out.

De Wilde was also able to impress his visitors with a number of large and valuable works. The auction catalogue does not feature Blaeu's Grote Atlas, but it does include his Toonneel des aerdriicx oft nieuwe atlas, one of the editions in six volumes printed between 1642 and 1664 (folio no. 1, see fig. 9). The costly celestial map by Andreas Cellarius, Harmonia macrocosmica, 166o or a later edition, a book that is still sought after, probably had its place on the same shelf (folio no. 8). In the same category is the well-known and imposing illustrated

19 Uffenbach, Merkwürdige Reisen durch Niedersachsen, Holland und Engelland, 3 vols. (Frankfurt etc. 1753-4), vol. 3, pp. 636-7: 'Clavicule de Salomon Roy d'Israel traduite d'Ebreux en Italien \& mise en françois \& les oraisons \& les conjunctions en latin avec les cercles les figures \&c.' (Uffenbach, who had bought a Claviculae manuscript in The Hague, also quoted the title of the first chapter). On this text see Carlos Gilly in: Marsilio Ficino e il ritorno di Ermete Trismegisto / Marsilio Ficino and the Return of Hermes Trismegistus, ed. Sebastiano Gentile \& Carlos Gilly, sec. ed. riveduta (Firenze 2001), pp. 228-9. On magical gemstones see Van den Bercken \& Verberk, op. cit. (n. 1), pp. 43-7. 
Elsevier Bible of 1663 (folio no. 10, erroneously referred to as '1653', see fig. 9). Apart from a few works by Erasmus in translation, De Wilde also owned the latter's Opera omnia, printed in Leiden in ten substantial volumes in the years 1703-1706 (folio no. 11, see fig. 9). The twelve parts of the 'treasure chamber of Roman antiquities' were naturally to be found on the shelf reserved for folio formats: Johannes Graevius, Thesaurus antiquitatum Romanorum, 1694-1699 (folio no. 19). Being a Remonstrant, De Wilde had no problems with Pierre Bayle's critical reference work Dictionnaire historique et critique; he owned the second edition of 1702 (folio no. 166). That he owned a copy of the first edition, 1525 (!), of Albrecht Dürer's seminal work of geometry Underweysung der Messung (folio no. 244), is undoubtedly connected to his collection of mathematical instruments.

These precious works, often richly illustrated with prints, are akin to the section on 'Prints' in the 1722 catalogue, as these are not individual engravings or etchings but plate books, such as Artus and Hubertus Quellinus's Voornaemste statuen ende ciraten vant konstrijck stadthuys van Amstelredam. De Wilde must have owned the first edition of $1655^{-1663}$ or the second one of $1665^{-1668}$ (no. 10), both editions were published in two volumes.

None of the books from the 1722 auction catalogue have been traced so far. Like most book collectors, De Wilde did not have a bookplate; his books were also not marked in any other way. The ornaments on the parchment bindings of some of the copies of his three published volumes were made with the same finishing tools and feature the same design, so that one might speak of a 'De Wilde Bindery', which produced a number of gift copies in more or less similar bindings for the author. ${ }^{20}$ The binding of the previously mentioned guest book, however, is tooled differently than those produced by this bindery.

\section{Reactions of Contemporaries}

The third source for the study of De Wilde's library is more modest in scale: they are comments by contemporaries. There were many who sang the praises of his art collection-usually in the entries in the guest book or in the preliminary poems to his three publications-, but only two persons ever actually commented on the library, and even then they only spent a few lines on the subject. Uffenbach - who incidentally visited seven other Amsterdam collections-has already been mentioned a few times: in the account of

$20 \quad$ Thus Jan Storm van Leeuwen, Dutch Decorated Bookbinding in the Eighteenth Century ('t Goy-Houten 2006), vol. 1, pp. 165-72, 218-25, 730-1; vol. 3, pp. 5-7. 
his visit to De Wilde he referred to a few manuscripts shown to him by the owner. In addition to some astronomical manuscripts which are not specified, Uffenbach named the earlier mentioned manuscript of the Clavicules de Salomon. He was more expansive on the subject of an-admittedly very collectable-manuscript with drawings in pen of busts of Roman emperors written by the architect, antiquarian, numismatist and coin dealer Jacopo de Strada. The manuscript in question must have contained the designs for the illustrations in Strada's Imperatorum Romanorum [...] imagines, a work published in 1559. Neither the manuscript or the edition are included in the 1722 catalogue of De Wilde's books (though another work by Strada is listed: quarto no. 50 ); the manuscript does occur, however, in the above mentioned catalogue of De Wilde's art collections of 1740/1741.

Ludolf Smids, author of emblem books based on classical literature, dedicated one of these volumes to De Wilde: De Roomsche keiserinnen of 1688 (a work incidentally not to be found in the auction catalogue). He was very grateful not only to have been admitted to 'UEds Medali-ryk Kabinet' (Your Honour's richly medalled cabinet) but also for having been allowed to consult 'UEs uitneemende Boekenkas' (Your Honour's exceptional library). Smids, who was also on a good footing with Nicolaas Witsen and the artist Adriaan Schoonebeek (the latter had made etchings for some of Smid's works), offered one more remark on De Wilde's library in his contribution to the collector's guest book mentioned above dated 20 September 1690 (pp. 72r-74v):

De Boeken passen bij dit pand,

Als 't goud gekeurd en uitgeleezen,

Bij de alderêelste diamant. ${ }^{21}$

With the exception of an occasional reference, the modern secondary literature has devoted no more than half a page, namely a brief discussion of the 1722 book auction, to De Wilde's library. ${ }^{22}$

Most seventeenth-century private art collectors built a library to accompany their collections. ${ }^{23}$ De Wilde's book collection, too, primarily served to

21 (The books fit with this treasure [i.e. the coins] as assayed and superlative gold fits with the noblest diamond). The poem is included in Afbeeldinge van het medalie-kabinet van Jacob de Wilde (1691), and in Smids's Poësye (1694), pp. 14-17: 'Ter eeren het munte kabinet van de Heer Jacob de Wilde [...]. Geschreven in sijn E. Stamboek' (In honour of the numismatic cabinet of Mr Jacob de Wilde [...]. Written in his Honour's guest book). Wagenaar, art. cit. (n. 1), pp. 102-3. De Wilde does not feature in the list of book collectors in H. W. de Kooker \& B. van Selm, Boekcultuur in de Lage Landen 1500-1800 (Utrecht 1993).

23 Cf. Jan van der Waals, 'Met boek en plaat. Het boeken- en atlassenbezit van verzamelaars', in: De wereld binnen handbereik, op. cit. (n. 1), [vol. 1], pp. 205-31. 
support his art collection and his three publications on the subject. His was not really a scholarly library. He did own works on Antiquity in Latin, as it was the lingua franca of scholarship, but when it came to editions of classical authors he preferred to buy French or Dutch translations. Uffenbach observed he did not have a command of Greek. More than once, there is an ironic undertone in his account of the visit he paid De Wilde, which exposes the great Amsterdam collector as basically an amateur. Modern experts have expressed doubts about the value of his collections (many objects do not date to Antiquity, and sometimes they are blatant forgeries) and have deemed his publications (in particular his Gemmae) to be of no scholarly value. ${ }^{24}$ De Wilde did have dash, however: compare his Latin Selecta numismata, published in the large quarto format in 1692, with S. Schynvoets muntkabinet, printed in Dutch in the unassuming octavo format in 1695. For modern historians, the story of De Wilde's library may also serve to shed light on the iconographic game that was played in the seventeenth century, a game that focused on the various symbols on coins, gems and sculptures and could be played by all, including amateur collectors.

\section{Acknowledgment}

This article has been translated by Cis van Heertum.

24 See especially Kistemaker et al., op. cit. (n. 1), pp. 82-6. 